\title{
Collaboration of Educational Actors in Formulating Integrated Curriculum Based on Islamic Values in Aceh
}

\author{
Nur Hafni*1, Aiyub ${ }^{2}$ \\ ${ }^{1}$ Department of Public Administration, Universitas Malikussaleh, Aceh Utara, Indonesia \\ Corresponding Author: nurhafni.ian@unimal.ac.id
}

\begin{abstract}
The Province of Aceh has a robust legal basis and umbrella in implementing an education system based on Islamic values following the mandate of Law No. 11 of 2006 and is described in the provincial and district qanuns of North Aceh. Implementing the special autonomy policy in education gives the Aceh Provincial government the flexibility to develop creative and innovative Islamic-based programs following the characteristics of Aceh's privileges. This study aims to analyze the formulation of Islamic values-based curriculum education policies in primary education and the collaborative actors involved in forming Islamic values-based educational curriculum policies. The research was used the descriptive qualitative method. The informants were determined by purposive sampling. The study found no synergy of cross-actor in collaborative governance in the formulation of Islamic values-based Aceh education curriculum policies. Thus, the implementation of education programs based on Islamic values was interpreted and meant differently among agencies. In addition, the National Curriculum strongly dominated the implementation of Aceh education in primary education, while local policies on Islamic values were few. Therefore, the policies of providing education do not reflect the specificity of Aceh's privileges. Besides that, the Islamic-based education policy program was not explained in a more detailed derivative policy.
\end{abstract}

Key words: collaborative; governance; formulation; actors; islamic education curriculum;

\section{Introduction}

The problem behind this study is that the existing conditions of collaborative formulation of Islamic values-based educational curriculum policies are to integrate the values of faith, sharia values, and good values in the primary education curriculum. However, in practice, these values are difficult to accommodate in curriculum formulation, which is still tricky. In addition, there are differences in understanding and meaning in the formulation of the primary education curriculum. Nevertheless, the national policy on implementing education allows the Aceh Province to formulate a curriculum that can give a different color from other regions.

Balogh et al. (Subarsono, 2011) define collaborative governance as a process and structure of management and public policy formulation that involves many actors constructively from various levels, both government agencies, private parties, and the community, to achieve the public interest (Phares, 2004) and improved sector-policy (Bradle2012). The collaborative governance model requires all stakeholders to engage in dialogue to express their interests (Booher and Innes, 2002).

The education decentralization policy has contributed significantly to the realization of collaborative governance in formulating educational curriculum policies. A network of local government, community, and school involvement is established in decision making, thus giving birth to an autonomy policy in each region. Smith and Purkey (1986). In the context of the collaborative governance implementation, it has been interpreted through Law 11/2006 on governing Aceh. This policy is one of the critical indicators of special autonomy status to provide space for the implementation of quality education and to add local content materials following Islamic law. According to Prof. Dr. Darwis, A Soelaiman (2016), as an Aceh education expert stated that: 
"Aceh Province has historically had the best strategic planning concept in Indonesia so that Aceh has received a privileged status in the field of education. Therefore, Aceh Province should ideally be able to promote the development of Islamic law-based education, which is different from other regions, in accordance with its unique status and special autonomy so that it can encourage regions to have a better education system than other regions. (Source: Serambi, 19 September 2016).

The policy of Islamic values-based education in general education is a strategic policy of the local government in integrating a blend of religion (Islam) which is sourced from the Qur'an and hadith and culture (Aceh) that breathes Islamic teachings, which is combined with national culture. In content, Aceh's educational qanun aims to realize the development of personality values of the Acehnese generation who are pious and have good morals to create an intelligent, creative, and innovative era. This goal is in line with what was conveyed by Prof. Walidin, who explained that Aceh Province already has a strong legal basis and umbrella to realize an Islamic system in education. However, in practice, the concept and form of Islamic education are not yet clear enough for many people about what the idea and structure of Islamic education look like". (Source: daily analysis, Monday, November 16, 2015).

Based on this information, it can be described that conceptually there are weaknesses in the formulation of Aceh's education policies. It becomes an obstacle in the ratification of derivative policies based on Islamic values. This condition gives rise to different interpretations of meaning and interpretation between government actors and actors outside the government, one of which has an impact on the formulation of values in the Islamic values-based curriculum. Chapter IX on the curriculum, article 27 paragraph (1) describes the curriculum used in every education following national content standards and Islamic content, paragraph (2) the curriculum implemented Islamically in paragraph one is the entire learning process carried out in schools. (3) school curriculum at all types and levels as referred to in paragraphs (1) and (2) compulsory subjects: moral theology, Al-Qur'an, and hadith, fiqh, civic education, mathematics, natural sciences, social sciences. skills education, information technology, Indonesian language and literature, Acehnese arts and culture, English, Arabic, and Acehnese, as well as physical education and sports. (4) school curricula at all types and levels of education can add local content according to the needs stipulated by the Regent's regulation. Namely the executive (Regent), executive and implementing agencies, the second is a group of actors outside government institutions, namely from the dayah actors consisting of the ulama consultative assembly and the affiliation of the Traditional Islamic (dayah) teachers, then education observer institutions and teacher associations.

Based on the empirical phenomenon, collaborative governance owned by the parties involved has very limited authority in terms of the strengths and interests of each of these actors. So that it has implications for the primary education curriculum that does not reflect and accommodate the privileged values of Aceh, a collaboration between actors who play a role has not shown synergy in curriculum policy formulation. This study is an attempt to find answers to the main questions: "Why has Collaborative governance in the formulation of Islamic values-based curriculum policies not able to be described optimally? "The main question will be elaborated in further problems, namely how does collaborative governance in the formulation of Islamic-based curriculum policies in primary education in North Aceh Regency?.

\section{Literature Review}

Several theories in this study; policy theory, actor's role in policy formulation and collaborative governance, and Islamic values-based education models are the main theories used in reviewing curriculum policy formulation for Islamic values-based primary education in North Aceh Regency.

\section{Paradigm Development of "Public Administration"}

The paradigm of the development of public administration started from the era of "Administration Dichotomy" to the era of "Governance" until finally the birth of the concept of "Collaborative Governance." Collaborative governance is the topic of this study. The paradigm shift of public administration, according to Nicolas Henry (2007), is as follows: 
1. The Politics - Administration Dichotomy, 1900 - 1926.

2. The Principles of Administration, 1927 - 1937.

3. Public Administration as Political Science, 1950 - 1970.

4. Public Administration as Management, 1956 - 1970.

5. Public Administration as Public Administration, 1970 - Now

6. Governance, 1990 - Now

The last paradigm is "governance." Governance is defined as the exercise of power or authority by political leaders for the welfare of citizens. It has a complex process in which several sectors of society hold power, enforce, and disseminate public policies that directly affect society and institutions and also affect economic and social development (Tamayao 2014). The term "governance" is used to describe the fundamental processes of modern governance as distinct from traditional governance. (Ewalt, 2001). Basically, "governance" involves partnerships in carrying out government functions. These partnerships include involving local residents, community organizations, the public and private sectors (Gibson, 2011). The five principles of the "governance" paradigm include:

1. Network of institutions and actors from inside and outside the government;

2. Blurring of boundaries and responsibilities to address social and economic problems;

3. The interdependence of power between institutions involved in collective action;

4. The actor-network is autonomous and self-regulating; and

5. The capacity to get things done does not depend on the power of the government but uses its authority (Stoker, 1998).

Governance is widely used as an equivalent to replace the term "public administration" or at least refers to its equivalent quite a lot (Lan and Rosenbloom, 1992; Peters and Savoie, 1995; Salamon, 1989). In the context of expert opinion, it can be concluded that the concept of governance pays attention to the importance of the involvement of stakeholders in the decisionmaking process. This is due to the fact that the decision-making process and its implementation are increasingly complex with the challenges and problems faced.

\section{Key Elements of Collaborative Governance}

Collaborative governance includes informal and formal relationships in problem-solving and decision-making. Conventional government policy processes can be embedded in the broader policy process by facilitating collaboration between the public, private, and community sectors (Ansell and Gash, 2008). Collaboration is an activity that is fundamentally located in the management of social networks. Collaboration is a concept that describes facilitating and implementing involving multiple organizations to solve problems that cannot or cannot be easily solved by an organization alone. This opinion is supported by Bardach (Sudarmo, 2015), who defines collaboration as a form of joint activity by two or more institutions that work together to increase "public value" rather than working alone.

Collaborative governance is a set of arrangements in which one or more public institutions directly involve "non-state" stakeholders in formal policymaking processes. (Ansell and Gash, 2008). Edward DeSeve (Sudarmo, 2015) defines collaborative governance as an integrated system with managed relationships across formal and informal organizational boundaries with reconceptualized organizational principles and clear definitions of success. Robertson and Choi (2010) define collaborative governance as a collective and egalitarian process in which every participant has the authority to make decisions. Every stakeholder has the same opportunity to reflect on their aspirations. (Dwiyanto, 2011). From the definition put forward by Bovaird, it is clear that a partnership involves a form of cooperation that is more than just a cooperation contract. The cooperation described in the concept of partnership between the public and private sectors is the cooperation of each party who has concerns beyond the written contract. The compromise in the autonomy of cooperation and collaboration can be seen in the figure below: 


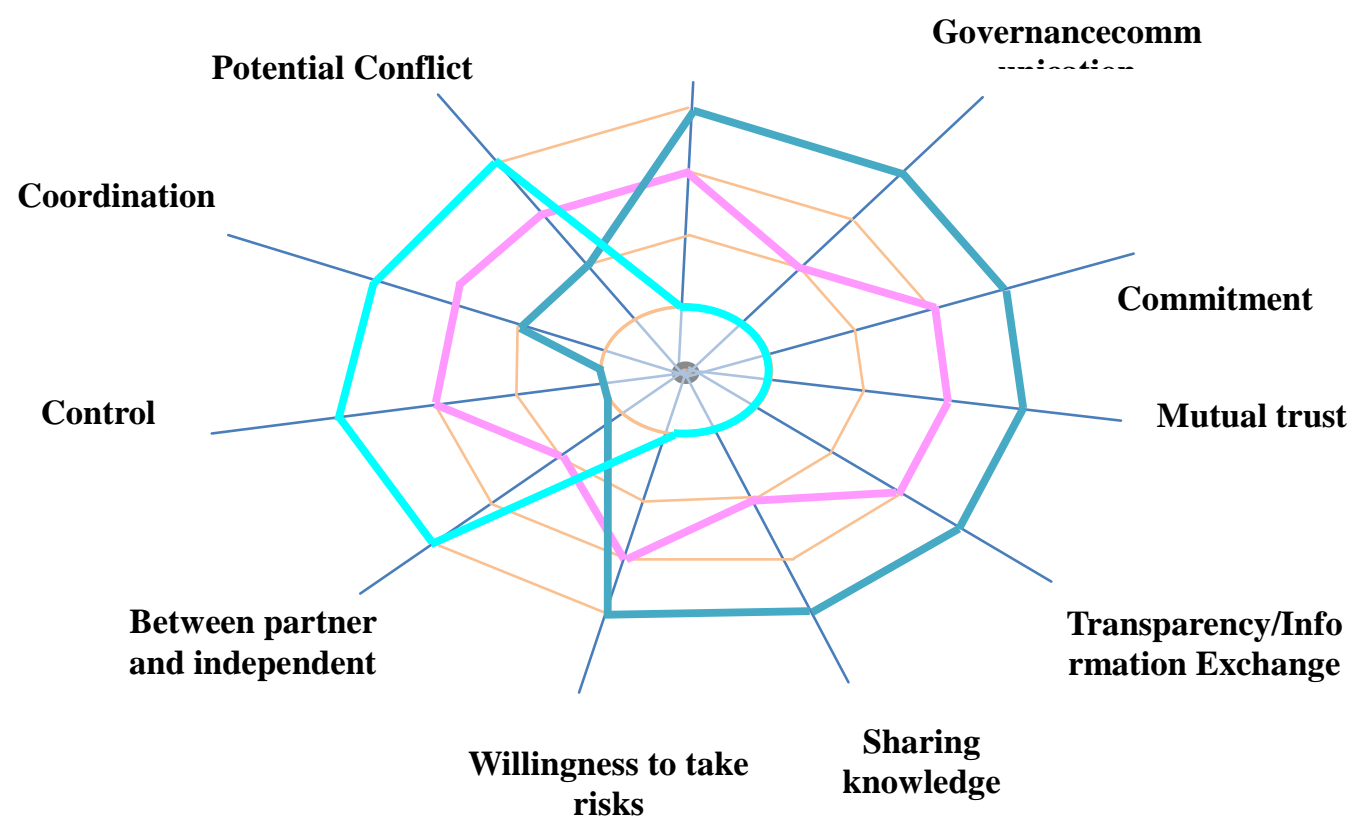

Figure 1. Long-term compromise in the form of cooperation and collaboration autonomy

Partnerships carried out by the government with institutions outside the government can be divided into several partnership arenas, namely:

1. Collaboration among internal government institutions.

2. Collaboration between government institutions and private institutions.

3. Partnerships between government and civil society institutions.

Collaboration between government institutions (internal) in the implementation of problemsolving, the government has departments that focus on one sector. Still, government agencies also handle public services together (cross sectors) due to the need for involvement between agencies. The principles of collaborative governance presented by Goldsmith and Kettl (2009), Saiger (2011) and Schottle, Haghsheno and Gehbauer (2014), by Agus Dwiyanto (2018) all of the principles mentioned can be concluded into only three things that need attention, namely the focus on the value dimension, the institutional dimension, and the process dimension. For example, commitment, mutual trust, willingness to compromise are value dimensions. The institutional dimensions can be seen in networks, governance, partnerships, while the process dimensions can be seen in access to resources, accountability, and others.

\section{Public Policy Formulation and Dimensions of Policy Networks}

The term networks were first used in the 1940s and 1950s to analyze and map personal relationships, interrelationships, and dependencies in policymaking (Parson, 2011: 187). Policy networks can stimulate the strengthening of policy legitimacy and anticipate potential conflicts that will occur when a policy has been formulated. The pattern of coordination that is built is not hierarchical (hierarchical authority) but is bargaining and negotiating (horizontal bargaining).

This confirms that there is no longer a centralized decision-making process Heclo (, 1978), Hanf and Scharpf (1997). This perspective critiques the single actor (state) conception that has dominated the public policy formulation process. With this pattern of relations, interest groups on a policy issue have access to the formulation process. According to Anderson (2006: 12), policy formulation is how to develop options or alternatives to solve these problems and who participates in policy formulation. Whatever happens at this stage will significantly determine the success or failure of future policies. 


\section{Methods}

The research location is in the education and culture office of Aceh Province and the education office of North Aceh Regency. The academic reason for choosing the location is that the autonomous process of formulating policy qanuns is at the provincial level; the North Aceh Regency is drafting an Islamic value-based Aceh education curriculum. This study is about crosssector collaboration in curriculum education policy formulation by referring to the model of Schottle, Haghsheno, and Gehbauer (2014).

\section{Research design}

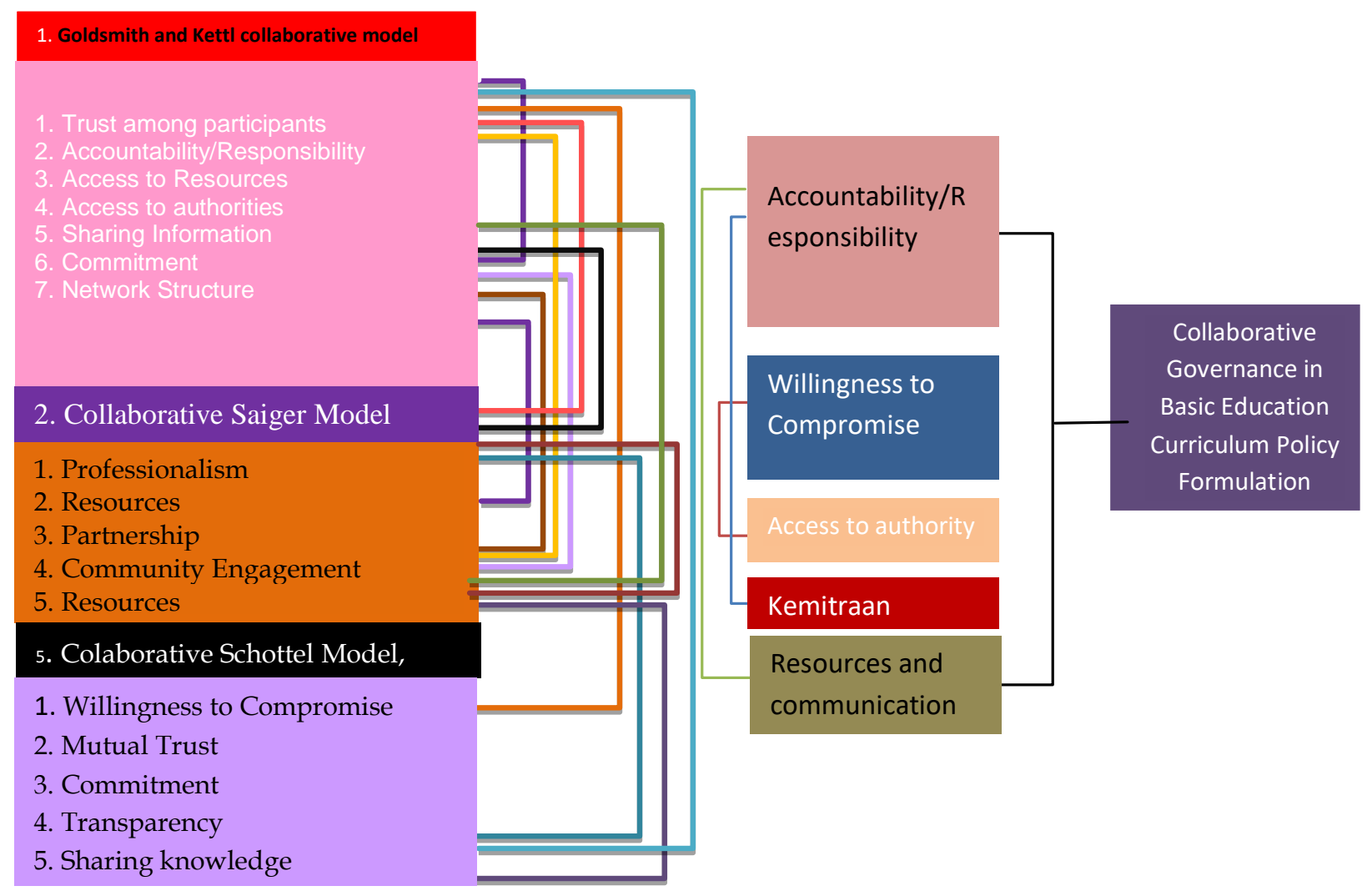

Figure 2. The framework of Goldsmith and Kettl (2009), Saiger 2011 and Schottle, Haghsheno, Gehbauere 2014

\section{Data collection techniques}

Research Approach quoted from K. Yin (2006) with a case study research approach equipped with several data collection techniques, triangulation techniques carry out data analysis. The method used descriptive-qualitative analysis, as well as explorative qualitative. This approach was used to find out collaborative in formulating educational curriculum policies used at the provincial and district levels of North Aceh. Primary data sources and secondary sources. Data collection techniques used were in-depth interviews, observation, and documentation studies. Meanwhile, the data analysis was carried out with descriptive qualitative and exploratory methods, describing the research data collected. After the data was collected, it was linked to the proposition and its interpretation through the following steps: 1) open coding, 2) axial coding, 3) selective coding. Data analysis techniques are carried out by reviewing all the data that can be obtained. After being studied, they are reviewed and then carried out data reduction by making abstractions. 


\section{Results and Discussion}

\section{Collaborative Governance in Formulating Curriculum Policy for Education Implementation}

Collaborative governance is a concept that describes the process of facilitating and implementing involving multiple organizations to solve problems that cannot or cannot be easily solved by an organization alone in the formulation of Islamic-based curriculum policies in primary education in North Aceh Regency. The substance of collaborative policy formulation as an effort to Islamize the education system that is based on the Qur'an and Hadith, then as the basis of policy for the implementation of education in Aceh is very dependent on the formulation of the principles, functions, and objectives as well as the foundation of the education curriculum, as the most important element for policy success. In efforts to realize Islamic education in Aceh Province, it is necessary to reform, reformulate, restructure, reorganize, transform, renovate, and modify the Aceh education system from the content and policy context. Field studies on collaboration indicators include communication, accountability, access to authority, access to resources, commitment, trust, structure, and governance in curriculum formulation in primary education.

\section{Building Accountability Between Actors In Collaborating}

The province of Aceh has particular authority in the field of education, through the policy of the Aceh education system based on Islamic values following the mandate of the National policy rules stipulated in Law No. 11 of 2006, which is described in the qanun for the provision of education to provide space for the province of Aceh to carry out education policies following expectations. Acehnese people are known as Islamic and religious. The concept of the Islamic education curriculum was developed with the paradigm of integrative unanimity. These aspects include a) aspects of faith and piety that contain life values; b) intellectual aspects, and; c) skill. The placement of aspects of faith and taqwa on the priority and ideally marks the goal of Islamic education in the formulation, which is humanism-theistic. The network structure is the link between one element to another and reflects the physical aspects of the network being handled. Then, in collaborative governance, the network elements should not form a hierarchy, that is, the power of one party. So that in collaborative governance, the network must be organic with the network structure involved, namely, there is no hierarchy of power, domination, and monopoly. So, all parties have the same rights, obligations, responsibilities, authorities, and opportunities for accessibility in achieving common goals.

Field findings show that the Aceh Islamic curriculum is a national curriculum added with Islamic values and local wisdom. The national curriculum is still implemented according to minimum standards by integrating Islamic materials, values, and local content into Aceh. As a region that applies Islamic law, this curriculum is a regional need to develop student competencies that are following regional potential and Islamic characteristics, following the Qur'an and Sunnah, which are cultural and religious-based Aceh (strength and opportunity), in Aceh. The Aceh government law provides a chance to apply Acehnese religious and cultural values in the implementation of Islamic education. Empirical phenomena based on research results show that the curriculum in primary education in North Aceh Regency has adopted the National curriculum (K13) plus Islamic, and there are still some schools that are still adopting the KTSP curriculum. In contrast, the curriculum is implemented in primary education in North Aceh Regency, which is illustrated in the table below.:

Table 1. Primary School Curriculum of the Education and Culture Office, North Aceh Regency, 2018/2019 academic year.

\begin{tabular}{cccc}
\hline No. & Number of Primary Schools & Curriculum & Information \\
\hline 1 & 316 & Curriculum 2013 & \\
\hline 2 & 48 & Grade 6 KTSP & Grade 1 to 5 - Curriculum 2013 \\
\hline & & \\
& Total 364 & & \\
\hline
\end{tabular}

Source: Curriculum Division of North Aceh Regency Education Office 
The table data above describes that the implementation of the curriculum used in elementary schools as a whole has implemented the 2013 curriculum. From three hundred and sixty-four elementary schools in North Aceh Regency, as many as three hundred and sixteen elementary schools implemented the curriculum 2013. The remaining forty-eight schools are still implementing the education unit level curriculum (KTSP) in grade 6 elementary schools. In this case, the government is targeting that by 2021 every school in the North Aceh Regency has implemented the curriculum 2013 (K13).

Table 2. Secondary School Curriculum (SMP), Education and Culture Office of North Aceh Regency, 2018/2019 academic year

\begin{tabular}{cccc}
\hline No & Number of Secondary Schools & Curriculum & Information \\
\hline 1 & 38 & Grade 9 KTSP & $\begin{array}{c}\text { Grade 7 and 8 - } \\
\text { Curriculum 2013 }\end{array}$ \\
\hline 2 & 136 & Curriculum 2013 & \\
\hline
\end{tabular}

Source: Curriculum Division of North Aceh Regency Education Office 2018

The data above explains that the curriculum used in junior high schools in the education office of North Aceh Regency is mostly out of one hundred and seventy-four of secondary schools, one hundred and thirty-six have implemented the 2013 plus Islamic curriculum, the remaining as many as thirty-eight still adopt KTSP. One of the programs in the formulation of the integration of the general education curriculum with an Islamic values-based curriculum is to design an integrated curriculum revision. In this case, the North Aceh Regency Education Office includes these activities in the program in 2019. The form of the Curriculum 2013 (K13) plus Islamic is as follows:

Table 3. Curriculum Structure for Grade VII, VIII, and IX

\begin{tabular}{|c|c|c|c|c|}
\hline & \multirow{3}{*}{ Subjects } & \multicolumn{3}{|c|}{ Allocation of Study Time } \\
\hline & & \multicolumn{3}{|c|}{ PER WEEK } \\
\hline & & VII & VIII & IX \\
\hline \multicolumn{5}{|c|}{ Group A } \\
\hline 1. & \multicolumn{4}{|l|}{ Islamic education } \\
\hline & Al Qur'an Hadis & 2 & 2 & 2 \\
\hline & Moral theology & 2 & 2 & 2 \\
\hline & Fiqih & 2 & 2 & 2 \\
\hline & History of Islam & 2 & 2 & 2 \\
\hline 2. & Pancasila and civic education & 3 & 3 & 3 \\
\hline 3. & Bahasa & 6 & 6 & 6 \\
\hline 4. & Math & 5 & 5 & 5 \\
\hline 5. & Natural Science & 5 & 5 & 5 \\
\hline 6. & Social science & 4 & 4 & 4 \\
\hline 7. & English & 4 & 4 & 4 \\
\hline \multicolumn{5}{|c|}{ Group B } \\
\hline 1. & Art and culture & 3 & 3 & 3 \\
\hline 2. & Sports physical Education and health & 3 & 3 & 3 \\
\hline 3. & Craft & 2 & 2 & 2 \\
\hline \multicolumn{2}{|r|}{ Total Time Allocation Per Week } & 43 & 43 & 43 \\
\hline
\end{tabular}

Source: Education Office Curriculum Division, North Aceh Regency, 2018 
Based on the table above, it can be interpreted that the difference between general subjects and Islamic-based education is from additional subjects, namely the subjects of the Qur'an, Hadith, moral theology, fiqh, and the history of Islamic culture, these subjects are subjects of local wisdom. The data analysis shows that the content of value education Islam in general education is still very minimal, which can be accommodated only 4 hours out of 38 hours/week. Thus, the process of Islamization of Islamic-based education in Aceh is very dependent on the wisdom of each school. It has been implemented so far. Each school requires students to read short verses, read Yasin every Friday, and provide reading materials in Islamic form to actualize Islamic values.

\section{Building collaborative governance between actors}

The collaborative process is an important aspect; therefore, efforts are needed to build governance, a relationship of trust between governance actors. In addition, some rules are mutually agreed upon by each stakeholder, and there is the freedom to determine how collaboration is carried out. In this case, governance can be said to be governance if there is clear clarity about who is a member and who is not a member. Every stakeholder (including the public) must be involved in making policy decisions. (Goldsmith and Kettl, 2009). The research findings show that actors who collaborate in the formulation of an Islamic-based integration curriculum, among others, the first group are elite local government actors, namely the executive (Regent), executive (board of the North Aceh education commission), and implementing agencies including related agencies, such as the education and culture office. The regional development planning agency, the Aceh education assembly, the regional education assembly, the ulama education assembly, the dayah education office, as well as school principals and teachers within the North Aceh education office. The implementation of education in the field of elaboration of educational qanuns involves all important elements of education, based on information from interview data, that the role of elite actors in the elaboration of qanuns is still very limited in ability because there is a weakness in linking general education whose orientation tends to be very minimal, giving local actors the flexibility to implement the Islamization of basic education in general education as the basis for the guidelines of the Qur'an and Hadith, the limited time for children to study religious studies and study subjects in the context of local wisdom and the very high dependence of the budget on the central government for the implementation of education. These indicate that the actor, the elite lacks the power to fight for the community's interests, which are accommodated in the qanun for the implementation of Islamic education.

Based on the existing condition that the association of teacher institutions has not been actively involved in curriculum formulation, even though the association is one of the representative parties representing the aspirations of teachers, then the accountability of the knowledge integration program cannot be accounted for following policy objectives, this condition is caused by limited resources either by implementing agencies as well as budgetary resources as well as very limited facilities and infrastructure, thus giving rise to various interpretations and understandings between actors about the program, in this case, the executive and implementing agencies still interpret the science integration program differently, because there is no derivative policy that can explain details of the program objectives. The Islamization of the curriculum in basic education is a very urgent policy to be carried out to realize human civilization based on the values of monotheism. Access to the authority, which is still very limited due to regional autonomy at the provincial level, is a factor in the low commitment of elite actors at the local government level who are less able to show the attitude and political will of the local government, which has not been able to convince the public to realize basic education by integrating the value of general education with religious education. Interaction between actors has been formed in the formulation of Islamic values-based curriculum, where elite actors and implementing agencies have held meetings in the process of equalizing views on the Islamization program education, these activities also, of course, involve the role of actors from outside the government to hold meetings in common view about proposals and revisions to the Islamization of education program, but the results of the meeting have not been fully accepted following the cross-actor proposals. Routine cross-actor meetings are often held, but the results of these meetings have not 
been fully accommodated due to the limited autonomy at the district level. However, across these sectors, there are still various meanings in interpreting the criteria and policy objectives. Besides that, there is still a lack of serious effort in direct socialization to every school.

\section{Implementing agency access to Authorities in collaborating}

Sharing information is easy to access for members (Goldsmith and Kettl, 2009), protection of privacy, and limited access for non-members as long as it is acceptable to all parties. So that in collaborative governance, there must be clear information sharing and easy access to information for each stakeholder. Information sharing is easy to access for members, privacy protection, and limited access for non-members as long as it is acceptable to all parties. So that in collaborative governance, there must be clear sharing of information and easy access to information for each stakeholder.

Field findings indicate that there is still limited access by implementing agencies as members involved in the formulation of the integrated curriculum, where technical aspects often constrain the authority and authority of the actors owned to carry out their interests. This condition can be described by formulating the legality of the draft PERBUB for Islamic education by the Regent. Until now, the proposed draft has not been approved by the Regent, even though the policy is very urgent to be ratified so that there is a more detailed derivative policy so that the program objectives are not interpreted ambiguously by each actor. It depends on the decisions of elite actors, thus indicating the strength of intervention from elite actors in setting program objectives. One of the weaknesses is the dominance of national policies in the Islamic education curriculum. Elite actors and implementing agencies are looking for alternatives by adding hours of Islamic value-based education to the education curriculum; these alternatives are not responded positively by implementing agencies due to budget constraints to appoint dayah teachers in general education because they are inefficient in regional budgets because teachers who are in $33 \%$ of general education are still honorary status while reducing national subjects also has problems with teacher certification in the field of study. As a result, the program is less effective in having an impact on changes in student values.

Existing data interprets that there is a weakness in the authority of elite actors at the regional level so that proposals and findings from implementing agencies do not receive priority and attention from elite actors, the interaction of relationships between each actor shows strengths and interests in fighting for the vision of the qanun for the provision of education, besides that There is attention that has been missed by elite actors and implementing institutions, especially in the formulation of an Islamic values-based integration curriculum, where good relations with teacher institutions have not yet been established, while teacher associations are actors who have the power and interest in fighting for the aspirations of teachers in implementing educational qanuns, problems and challenges in the field are also better known by teacher association institutions. The weak authority, power, and interest in improving the quality of education were also conveyed by the association of committees and school foundations, which stated that the low quality of education was due to the lack of functioning of the context of policymaking at the elite actor level.

\section{Commitment in Fighting for Program Goals}

Commitment to shared goals is why networks must exist because of the attention and commitment to achieving positive goals shared. These goals are usually found in the general mission of government organizations. In addition, the commitments made cannot be in favor of one of the stakeholders or policymakers. The existing collaboration only benefits one party, so the commitment built-in collaborative governance must be of mutual interest in searching for joint solutions (Schottle, Haghsheno, and Gehbauer (2014).

Commitment Elite actors and implementing agencies and actors outside the government agree to fight for public aspirations following what is mandated in the qanun on education, so in terms of qanun revision and the process of integrating knowledge in the general education curriculum, it has been carried out by cross-actor. The legislature has formulated the qanun for the implementation of education by inviting elements of implementing agencies and hearings with dayah teachers to discuss the integration curriculum, and revision is needed because several 
qanuns are considered expired. The executive will take the initiative to re-propose and be reapproved by the plenary legislature.

Christopher Stoney and Diana Winstanley argue that researchers should clarify their position concerning their beliefs and positions about who can be viewed as valid stakeholders in order to avoid bias (Stoney and Winstanley, 2001). Collaboration can be seen from the commitment of each actor, both elite actors, implementing agency actors and actors outside the government such as (non-governmental organizations observing education and teacher associations), the association of committees and school foundations (BMPS), as well as the visitation agency for school accreditation (BAPSM), all elements of the stakeholders, a focus group discussion has been carried out in the formulation of a policy draft for the derivation of the Islamization of education, as well as the revision of the qanun on the implementation, the event was held under the regional education council, all parties positively welcomed the activity. The research findings are what causes the collaboration process in the formulation to not optimally synergize due to weak authority at the elite district level in producing derivative policies. The discretion given by the central government to local governments is also relatively small so that political elites at the regional level are less able to produce programs innovative programs in Islamic education policy. Besides that, the carrying capacity of the resources is limited, so the impression of program implementation does not show seriousness.

\section{Trust between Actors}

Trust between participants is a professional or social relationship and belief that participants entrust information or efforts from stakeholders or other stakeholders in the network to achieve a common goal. So, in this case, each stakeholder must trust each other because it is a form of professional relationship formed to successfully implement collaborative governance (Schottle, Haghsheno, and Gehbauer (2014).

Based on the existing model that the integrated curriculum is based on Islamic values, it is a public aspiration mandated through UUPA No. 11 of 2006, which is described in Provincial Qanun No. 9 of 2015 concerning the implementation of education, wherein the principle of goals and functions that are squeezed out in the goals of Islamic education emphasize that there are differences the color of education in Aceh with other provinces following the specificity they have. The glory of Aceh's education in the past started from the educational curriculum; historically, history recorded that dayah had a big role as an educational institution that educated generations of the nation in the development of religion, state, and nation. Dayah alumni have become pillars of people's lives. The qanun on the implementation of education in formal education provides a great opportunity for dayah actors to be involved in implementing Islamic education policies. The dayah teacher affiliation program to general education gives the dayah teacher discretion to apply their knowledge in formal education.

Elite actors have established cross-sectoral cooperative relationships and have given trust to dayah actors to collaborate in creating an integrated curriculum based on Islamic values. General education teaches worldly things and how to integrate general education knowledge with religious knowledge that is ukhrawi. As stated in the mandate of the UUPA and the contents of the qanun for the administration of education, in terms of teaching methods between the teaching system in the dayah and in general education, it is certainly much different. However, the role of the dayah actor in curriculum formulation has not received a common view from government agencies regarding the meaning of Islamic-based curriculum integration as mandated in the qanun on education.

Commitment and synergy of actors in all ranks of Aceh's elite officials holding a big hand to achieve the success of the formulation. Dayah actors have a very important and strategic role in Aceh, dayah scholars and alumni become symbols and enthusiasm for the community in providing a positive image of education, and public confidence in the progress of education, the history of Aceh's struggle proves the role of ulama and dayah actors as social control in society. The common understanding between elite actors, implementing agency actors, and dayah actors and non-governmental organizations is always carried out through seminars and studies 
conducted through focus group discussions. As can be seen in the picture below, where the chairman of the regional education council opened the activities for the realization of derivative regulations in the Islamization of education, as shown below.

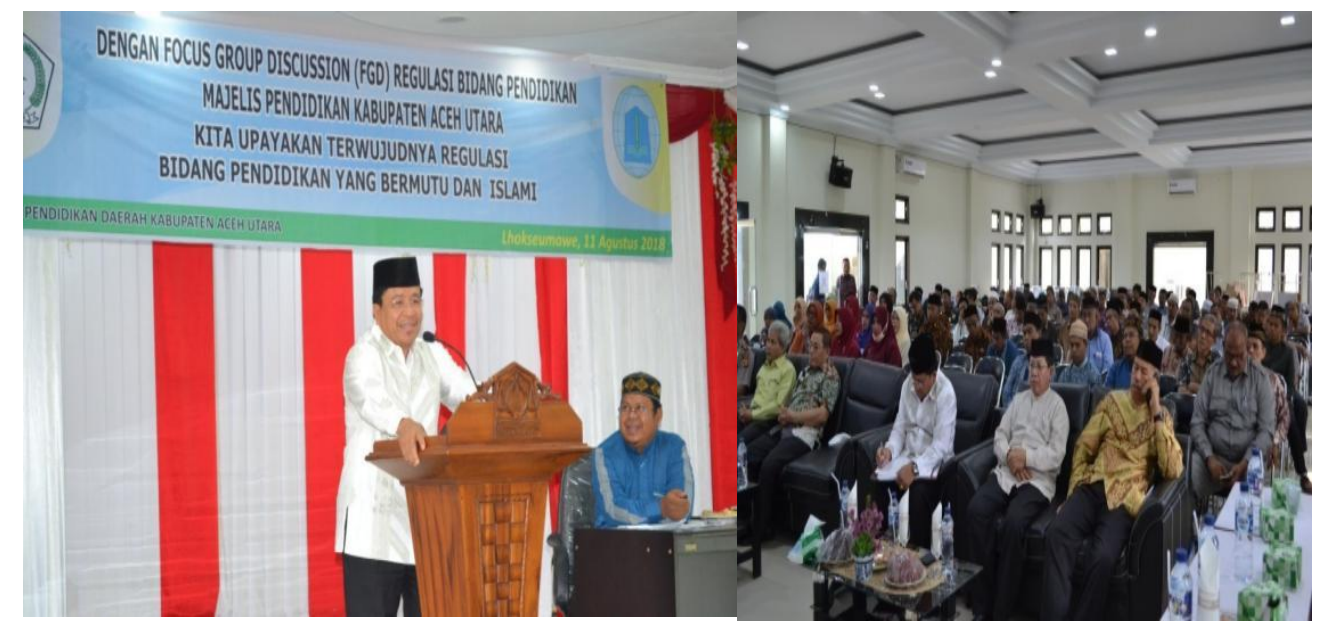

Figure 3. Opening of the Focus Group Discussion on the revision of the qanun for the implementation of Islamic values-based education (Photo: MPD Documentation of North Aceh Regency, August 11 2018)

Based on interview data and documentation, the focus group discussion activity was given full authority by the regional government to the regional education council to discuss the draft qanun for education, the activity involved cross-sectoral actors, including elite actors, namely the Regent, leaders, and members of the legislature, as well as from institutions involved. Including the Development Planning Agency (Bapedda), the Education and Culture Office, the regional education council, the Ulama education assembly, and the dayah education assembly, and representatives from associations of education observers and academics of the affiliation of dayah teachers. The programs that are prioritized in implementing Islamic values-based Aceh education this year are three activities. First, the revision of the Islamic education curriculum that has been carried out in 2019. Second, teacher recruitment and debriefing of Islamic education teaching staff, and third, curriculum implementation integrated Islamic education. These activities are contained in the school management program, which can be seen in the table below:

Table 4. Realization of Programs and Activities of the Education and Culture Office - North Aceh Regency in 2019

\begin{tabular}{llclc}
\hline No & $\begin{array}{l}\text { School Education Management } \\
\text { Program }\end{array}$ & $\begin{array}{c}\text { Source of } \\
\text { Funds }\end{array}$ & $\begin{array}{c}\text { Performance } \\
\text { Achievement Target }\end{array}$ & $\begin{array}{c}\text { Funding } \\
\text { Needs/Indicative } \\
\text { Ceiling }\end{array}$ \\
\hline 1 & $\begin{array}{l}\text { Implementation of the National } \\
\text { Examination, School Examination, } \\
\text { and National Standard } \\
\text { Examination ( for Primary School } \\
\text { / Secondary School) }\end{array}$ & APBK & 24.944 students & 757.248 .000 \\
\hline 2 & $\begin{array}{l}\text { Withdrawal of Drop Out Students } \\
\text { (Retrieval) }\end{array}$ & APBK & 91 students & 104.580 .600 \\
\hline 3 & $\begin{array}{l}\text { Formulation of Integrated } \\
\text { Curriculum for Islamic Education }\end{array}$ & APBK & $\begin{array}{l}\text { Curriculum Document 5 } \\
\text { Syllabus Module }\end{array}$ & 413.377 .440 \\
\hline 4 & $\begin{array}{l}\text { Recruitment and Debriefing of } \\
\text { Islamic Education Teachers }\end{array}$ & APBK & 535 people & 1.483 .235 .040 \\
\hline 5 & $\begin{array}{l}\text { Implementation of Islamic } \\
\text { Education Integrated Curriculum }\end{array}$ & APBK & 493 schools & 2.183 .391 .600 \\
\hline
\end{tabular}

Source: Education and culture office of North Aceh Regency 
The table above provides information for the implementation of Islamic values-based education, which prioritizes the performance of an integrated Islamic education curriculum, in which the curriculum provides opportunities for local curricula to provide subtle colors that are characteristic of Acehnese, as well as the characteristics of the Acehnese people, for the implementation of these activities the allocation of funds sourced from the district budget. According to the head of the North Aceh legislature, the performance of Islamic education activities carried out are;

Based on this information, it can be interpreted that the synergy between actors in the implementation of the Islamization of education is still general and not yet specific to Islamic education. In contrast, the implementation that has been carried out relates the material to general lessons with religion. For the Aceh region, it is good to have integrated Salafi and public schools after the midday prayer. There are additional hours of religion, general, Salafi, and integrated education in the field of Islamic education; the existence of integrated education so far has not been carried out optimally.

\section{Conclusion}

This study aims to obtain a comprehensive picture of collaboration between actors in the formulation of an Islamic-based integration curriculum, and it can be concluded that,

a) Collaboration between actors in curriculum formulation still has several weaknesses, where the communication built between actors in collaborating has not found the same understanding and meaning. In addition, the aims and functions of the policies extracted from the principles outlined in the qanun have not been fully able to be included in the values of the science integration curriculum due to the lack of time given in the national curriculum to the Islamic values-based curriculum.

b) Access owned by elite actors and implementing institutions is still limited both access to authority and access to resources so that the values integrated with the Islamic value-based education curriculum have not been comprehensively interpreted to actualize the values of faith, sharia values, and moral values with an approach the verses of the Qur'an, the axiological approach and the monotheistic approach,

c) The role of each actor in collaborating is still weak. It is based on the interests and strengths possessed by each actor so that it affects the understanding of interpreting the contents of the qanun on the implementation of Islamic values-based education.

\section{Recommendation}

Collaboration between actors in the formulation of an Islamic values-based integration curriculum is still complex and full of interests and powers, so it needs to be addressed immediately:

a. Minimizing ego-sectoral and tug-of-war between actors, both at the central, provincial, and district levels, according to the authority and role of each actor following the main tasks and functions that have been regulated in the qanun for the provision of education.

b. The need for a comprehensive study of the values that are integrated with the curriculum based on Islamic values by incorporating the values of faith, sharia values, and good values. Through three approaches to the verses of the Qur'an, the axiological approach and the monotheistic approach.

Each actor is given the same accessibility in determining their actions, attitudes, and resources, so that each actor is dependent and feels trusted to exchange messages and ideas.

\section{References}

Ansell, C\& Gash.A. (2008). Collaborative Governance in Theory and practice. Journal of Public Administration Research and Theory . 18 (4),543-57.https:/ / doi.org/10.1093/jopart/mum 032,

Anderson, James, 1975. Public Policy Making (second edition, New York: Holt Rencart and Winston

Booher.D.E.\& Innes, J.E.(2002)Network Power in Collaborative planning Journal of planning education and research. 21(3) .221-236. https://doi.urg/10.1177/0739456X0202100301 
Bradley.Q (2012). A" Performative"Social Movement: The Emergence ofCollective Contention within Collaborative Governance. Space and Polity.16 $\quad$ (2) $215 \quad-232$. https://doi.org/10/1080/13562576.2012.721504

Baska.B. (2012). The Paradigms of Public Administration Re-Examined: A Reflection Journal of Public Administration.47(1).23-67

Dwiyanto, A. (2003). Kependudukan dan Kebijakan UGM. Reformasi Tata-Pemerintahan di $\quad$ Indonesia. Pusat Studi

Dwiyanto, A. (2011). Penilaian Kinerja Organisasi Pelayanan Publik. UGM.

Dwiyanto, A. (2018). Mencari Identitas Ilmu Administrasi Publik di Indonesia, Gadjah Mada University Press.

Ewalt, J. A. G. (2001). Theories of Governance and New Public Management: Links to Understanding Welfare Policy Implementation. Igarss 2001, 1, 1-5. $\quad$ https://doi.org/10.1007/s13398-014-0173$\underline{7.2}$

Gibson, R. (2011). A Primer on Collaborative Multi-Level Governance. In Canadian Regional Development: A Critical Review of Theory, Practice, and Potentials

Goldsmith, S., \& Kettl, D. F. (2009). Networks, The Key to Networked Government Government Unlocking The Power of Network. The Kay to Networking governance

Henry, N., 2007. Public administration and Public Affairs. Sixth Edition. Englewood Cliffs, NJ.: Prentice-Hall.

Ikeanyibe, O. M. (2016). Uniformity in Local Government System and the Governance Model in Nigeria. 147-161. https:// doi.org/10.1177/0021909616666105 Journal of Asian and African Studies, 53(1),

Jones, Charles O., 1984. An Introduction to the Study of Public Policy (Third Edt.) Monterey Brooks/ Cole Publishing Company,

Salamon, L. M., \& Lund, M. S. (1989). Beyond Privatization: The Tools of Government Action. Urban Institute Press. https://books.google.co.id/books?id=BXI2nGfivJQC

Schöttle, A., Haghsheno, S., \& Gehbauer, F. (2014). Defining Cooperation and Collaboration in

the Context of Lean Construction.Proceedings IGLC-22, 1269-1280.

Seigler, D. (2011). Renewing Democracy by Engaging Citizens in Shared Governance. Public Administration Review, 71(6), 968-970. https://doi.org/10.1111/j.1540- 6210.2011.02452.x

Suwitri Sri. Jurnal Delegasi, Jurnal Ilmu Administrasi, STIA Banjarmasin, Vol. VI No. 3, Januari 2008, Terakreditasi KepDirjenDikti No. 56/ DIKTI/ KEP/ 2005)

Subarsono, 2008. Analisis Kebijakan Publik, Yogyakarta, Pustaka Pelajar

Sudarmo. (2015). Menuju Model Resolusi Konflik Berbasis Governance: Memuat Pengalaman Penelitian Lapangan tentang Isu Pedagang Kaki Lima Dan Konflik Antar Kelompok. Sebelas Maret University Press.

Tamayao, M. J. M. (2014). what is governance? Law, Politics and Philosophy. https://tamayaosbc.wordpress.com/2014/08/21/what-is-governance

Phares, D. (2004). Metropolitan Governance Without Metropolitan Government? Ashgate.

Yin Robert K.(2006). Studi Kasus ; Desain \& Metode. PT Raja Grafindo Persada, Jakarta.

Undang-Undang Nomor 11 Tahun 2006 tentang Pemerintah Aceh.

Qanun Aceh Utara No 4 tahun 2012 Tentang penyelenggaraan pendidikan Serambi Indonesia Dana Otsus Menurut UU Jumat, 14 Agustus 2015 14: 14. 